\title{
Conceptualistic Pragmatism
}

\section{Terry Pinkard}

\section{OpenEdition}

\section{Journals}

Electronic version

URL: http://journals.openedition.org/ejpap/1338

DOI: 10.4000/ejpap.1338

ISSN: 2036-4091

\section{Publisher}

Associazione Pragma

\section{Electronic reference}

Terry Pinkard, «Conceptualistic Pragmatism », European Journal of Pragmatism and American

Philosophy [Online], X-2 | 2018, Online since 11 January 2019, connection on 30 April 2019. URL http://journals.openedition.org/ejpap/1338 ; DOI : 10.4000/ejpap.1338

This text was automatically generated on 30 April 2019.

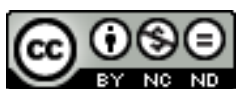

Author retains copyright and grants the European Journal of Pragmatism and American Philosophy right of first publication with the work simultaneously licensed under a Creative Commons AttributionNonCommercial-NoDerivatives 4.0 International License. 


\title{
Conceptualistic Pragmatism
}

\author{
Terry Pinkard
}

I

1 American pragmatism, like German idealism, was created by a generation who had collectively suspecting that they were going to have to live unprecedented lives. The paths through life that their parents and grandparents had traced seemed to offer no effective guide, and they thereby felt that they had to imagine different ways of thinking about life, the world, and even about thinking itself. For the pragmatists, the background was the American Civil War, the second scientific revolution (in chemistry and, in Darwin's biology), and industrialization and its accompanying brutalities and dislocation. ${ }^{1}$ For the idealists, it was the contradictions deeply twisted into the fragmented social and political world of Germany prior to and immediately following the French Revolution. In both cases, there was the generational experience that they could not be the people who fit into that world, and that things therefore were going to and had to change.

2 Of course, there were also great differences. Most notably, the early idealists did not experience industrialization in Germany, even if they did experience some of the shocks its early appearance in England had produced. Likewise, it was not the violence of a civil war but the violence and promise of the French Revolution that spurred their imaginations. As we might put it, for both of them - idealists and early pragmatists - the problem was that of grasping their own times in thought and in a thought that was also not simply relative to or merely expressive of the times but also the way thought "now" had to understand its prospects and possible limits.

3 For both idealists and pragmatists, the key word was "experience" - and in both cases in the German sense of Erfahrung. This was not the experience of a sense-datum or a fleeting moment or a raw feel. It was rather the experience from which one learned something, a more concrete conception of an encounter with a sometimes recalcitrant physical and social world. It was not accidental that Hegel's original title for his first real book, The Phenomenology of Spirit, was the Science of the Experience of Consciousness. The idealists joined to that conception of "experience" the rhetoric of "life" and the "organic," of an 
overall purposiveness to be found within things, whereas the pragmatists coupled experience with a rhetoric of "openness" and an interest in the logic of inquiry. In both cases, there was a shared conception of the key role of subjectivity-as-activity in thinking about the world, and rejecting, as Dewey later encapsulated it, the "spectator" view of knowing and acting. (It would be interesting but wildly beyond the scope of this paper to contrast the British response of the "absolute idealisms" of Green and Bradley, et al. to the modern British experience.)

crucially, in both cases, the idealists and pragmatists were responding to the modern worry which reaches its high tide in Kant's philosophy about the limits and possible limitations of thought. Kant, as is well known, thought that given the pure forms of our own intuitive faculties, our thinking was necessarily restricted to appearances and could not progress to knowledge of things in themselves. Things in themselves were real, but they existed on the opposite side of the boundary between thought and the real. However, by the time idealism had moved on to Fichte, Schelling and to Hegel, the Kantian idea that our conceptual capacities are bounded by the forms of intuition was replaced by the idea of conceptual thought as boundless, as answering only to its own demands. ${ }^{2}$

5 To the pragmatists (as well as others), this seemed to be something like rationalism gone mad, a basic failure to learn the basic Kantian lesson about the limitations under which finite human beings have to think. The kind of openness to experience which the pragmatists extolled meant that we had to be open, as it were, to reality changing our minds for us so that continuous progress in thought can be actualized and the novelty of new learning could be vouchsafed. Pragmatism, as a logic of inquiry (to use Dewey's phrase) devised a way of looking to the real by way of theory that made theory (of all sorts, scientific as well as philosophical) open to new experiences and to novelties in social life and, crucially, to improvement. ${ }^{3}$

\section{II}

To jump ahead: By the end of the twentieth century and beginning of the twenty-first, pragmatism was certainly alive and well, but in one of its most influential shapes, it had been by and large formed not from the pragmatism of Peirce, Dewey or James but from the much less studied C. I. Lewis. Lewis described his own version in his book, Mind and the World Order, as "conceptualistic pragmatism" (1929: xi). It is Lewis' picture, more or less, of mind, world, inference and sensibility that has shaped the kind of contemporary pragmatism that finds its exemplars in the works of W. V. O. Quine, Wilfrid Sellars, Richard Rorty, and Robert Brandom. Much of this version of pragmatism consists in accepting Lewis's framework while attacking or shifting the ways in which the frame is put together. In particular, two attacks which are familiar to contemporary philosophers are the Sellarsian attack on the myth of the given and the Quinean attack on the absolute difference between the analytic and synthetic. Much of what remains after those attacks is Lewis' framework as redescribed and transformed without those two elements. It is thus worth turning back to Lewis' system if for no other reason than to remind ourselves where the current version comes from.

Without stretching terms too much, Lewis's position could be called Kantian pragmatism. ${ }^{4}$ We might sum up Lewis' view as the following: if there are limits to thought, they are set by reality, perhaps even by human reality; thinking is an activity, and it is the ends of 
such activities (the purposes) that set the standards by which we evaluate the means; something like Kant's categories are to be justified if at all in light of their utility for serving those ends. In Lewis' system, we thus see pragmatism and idealism coming together under the dominance of the pragmatic component.

III

8 Lewis's picture of mind and the world order can be easily summarized, although as with everything good the devil (or the lord) is in the details. Lewis's picture is characterized by stark contrasts, even dualisms (of the kind that Dewey, for example, would disparage). In Lewis's thought, there is the a posteriori versus the a priori, the given versus the constructed, the passive versus the active. This occurs within Lewis's larger picture of our contact with reality being through the senses, after which we then organize the data that comes in to us by way of the concepts we apply to the sensuous data.

Our most basic concepts are prior to all experience. They are what Kant calls the categories but which Lewis extends further than merely classificatory concepts to include all attempts at making sense of that which given to us in experience (including naming, classifying, defining, and inferring). ${ }^{5}$ Relations among concepts determine their meaning. The basic concepts - the categories - are a priori: They are true, if they are true, no matter what, as Lewis puts it, and they cannot be determined by experience itself. They are the results of acts of legislation, not abstractions from experience (ibid.: 127). Their meaning is analytic, not material, and to know the meaning of a concept is to know how it relates to other concepts. ${ }^{6}$ The use of such a priori concepts is implicit in our familiar modes of behavior, and getting clear on their meaning just is making explicit what is always, already there implicitly.?

The use of such categories is that of making sense of what is given in experience. "The given" is the empirical element in experience. It consists (Lewis's term) in qualia, which cannot be named, are ineffable and can only be indicated by phrases such as "looks like" ( ibid.: 123). Such "givens" are subjective and can never themselves be objects of knowledge. Knowledge, in this pragmatic-Kantian picture, requires the cooperation of two distinct faculties - concepts and sensibility - whose functions cannot be conflated or confused with each other.

11 Lewis notes that the German idealists and their kin deny any such givenness, holding that there can be no element of experience which figures into our judgmental activity which does not have the structure of thought in it. To speak anachronistically, Lewis denies the given is a myth at all. John McDowell's version of the attack on the myth of the given, for example, has to do with our spontaneity (our conceptual capacities) supposedly going deeply into our receptivity without remainder. ${ }^{8}$ Lewis's argument against that would be relatively straightforward: He agrees with McDowell up to a point: "[T]he objectivity of the real requires always construction by the mind. This thesis does not imply any denial that the given is independent of the activity of thought" (Lewis, 1929: 46). On its own, the given cannot be knowledge at all. Nonetheless, thought, our judgmental capacity, cannot alter the sensuous quality of experience. If I am seeing red, I am seeing red, and I cannot alter that by thinking otherwise (even though, as Lewis argues, "red" cannot be the name of any particular qualia, since qualia cannot have names). ${ }^{9}$ The "given" is simply that sensuous element of knowledge that we cannot alter by our own activity and which comes to the mind from the real itself. 

be any knowledge at all via the givens of experience. ${ }^{10}$ The given is ineffable, and there is no ineffable knowledge. All knowledge is discursive and thus conceptual in structure. Rationalist theories (and here he includes the idealists) err in thinking that since our categorial concepts are a priori and whose meaning cannot be determined by the given that such categories are therefore autonomous elements of knowing. ${ }^{11}$ The truth of the matter is pragmatic: Our a priori categories are not eternally fixed but are open to change, and the criteria for choosing which of them we legislate to experience is pragmatic in that they are judged in terms of how well they fit a goal. concludes, "is pragmatic, utilitarian, and its value, like that of the activity it immediately subserves, is extrinsic. It has value as an end in itself only so far as, in life, the activity is the goal, or at least the two cannot be separated" (ibid.: 145). Thus, the a priori categories that make sense of the otherwise ineffable givens of sensibility are themselves a social achievement, something legislated collectively and not products of "pure reason" nor are they matters of objective fact. The categories are guides to action, not descriptions read off of sensible data. ${ }^{12}$

Why then are there not different categories for different societies or even different individuals? Lewis's answer: Our own natural like-mindedness. Such like-mindedness is part of our natural history, which consists in natural needs and aspirations but also just as much consists in fashioning categories to better predict the course of events as we put the picture together with the givens of sensibility. ${ }^{13}$ We communicate with each other or have the same concept when we how our behavior implicitly expresses those concepts: "The concept is a definitive structure of meanings, which is what would verify completely the coincidence of two minds when they understand each other by the use of language" ( ibid.: 89). ${ }^{14}$ Unless there was an identity of meaning, there could be no genuine coincidence of minds. There is no identity of givens. This kind of like-mindedness leads to our having a common world that is the common human world, since "we do not expect to have a common reality with an insect" (ibid.: 113). Our common world is thus itself a social achievement.

Our knowledge of empirical objects can therefore only be a matter of probability. ${ }^{15}$ The real object is only "the given as conceptually interpreted," (ibid.: 117) and, as known, "the real object [...] is a construction." ${ }^{16}$ Ultimately, the real object would manifest itself only at infinity. Knowing is an infinite approximation to the real, so that the "totality of possible experiences in which any interpretation could be verified" (which would be infinite) "is the entire meaning of that interpretation" (ibid.: 32). Not merely do we not know the object fully (non-probabilistically) until the end of the endless series, we could also not know fully what we mean until the end of the endless series. Indeed, it would only be with a picture of what that would look like that we could assign the probabilities of these interpretations.

Given Lewis's view, there can simply be no transcendental deduction of the categories in Kant's sense, since what drives the need for such a deduction is the skeptical worry that our sensibility may present us with objects that do not fall under the categories. Meeting that worry drove Kant into his various formulations about how it must be that we impose the categories on experience such that no object could appear that violated any of the categorial requirements. No such limitation, however, can be put on the given by our concepts - that much is meant by "the given." We cannot put any limits on what might 
show up in our sensory experience. Nor can the given limit what possible categorial concepts we might construct. ${ }^{17}$ To underline the point: All the possible givens have no a priori concatenation that fixes in advance what qualia can appear. Such givens are not even constrained by logic itself, since the ultimate criteria for any logic would be themselves pragmatic, to be evaluated in terms of how well they too fit some purpose. ${ }^{18}$ If there are any limits to knowledge, they will have to be the limits to reality itself. The Kantian mistake, which Lewis attributes to all forms of phenomenalism (under which he classifies Kantianism) is that "from the relativity of knowledge to the mind, it argues to the impossibility of knowing the independent real" (ibid:: 173). The real object can indeed be interpreted or measured in a number of different ways, but that diversity of interpretation does not mean that the real object is beyond all possible knowability. There simply can be no realm of "in principle" unknowable things in themselves, even though there not only may be many things we do not know and even some that are beyond us because of natural facts about our makeup.

\section{IV}

Given that summary, where does Lewis's conceptualistic pragmatism stand in relation to its earlier forbearers in German idealism and his predecessors in American pragmatism, and where does it stand in relation to his later successors in pragmatism? With regard to the latter, we can see how Lewis's framework sets the shape for a good bit of the later pragmatism embodied by Quine, Sellars, Rorty and Brandom, much more so than does, say, James's or Dewey's pragmatism. The sharp dualisms that Lewis defends - conceptual understanding (the analytic nature of meaning) on one side, sensory givens on the other - provide a powerful picture of mind and world. Lewis's resulting picture was thus, most abstractly put: A causal connection (input), plus the sensory givenness of qualia, plus an inferential processing of the qualia, and then a propositional statement of the inferential interpretation of the qualia. Lewis's successors transformed that picture into what we can think of as embodying a tripartite causal and inferential view of the matter. First, there are the causal inputs on the minded organism (photons entering the retina, sound waves in the air vibrating bones in the ear, etc.); second, there are the causal outputs of the organism that respond to those causal inputs (among these causal outputs are observation sentences or phrases, such as "Lo, a cow" or "This is green"); and in between are the inferential movements within the mind itself (where "within" just means "internal to the inferential process"). Thus, a stimulus of red (a wavelength of a certain sort) affects the sensory apparatus, the inferential wheels begin spinning ("Well, if it's red, it's certainly not green"), and there is a causal, learned output, the production of a sentence. ("Whoa, that's red, all right.")

Quine took over this picture, but rejected the idea of purely conceptual meaning (analyticity) and substituted instead the image of a web of such beliefs in which some were more central than others but none was "conceptually" or "analytically" true. That left only the causal inputs and outputs (which, sort of in keeping with some of the science of his day, he interpreted behavioristically), and inferential connections (which in the term of art of a large part of contemporary philosophy is called "the normative") are reduced to beliefs to which we develop dispositions to assent or dissent. ${ }^{19}$ Quine took Lewis's already fairly naturalized framework which still had a separate place for philosophical reflection on the relation between mind and world and fully naturalized it 
to render it compatible completely with natural science as it was practiced in mid- to-late twentieth century culture. Quine, as it were, deconceptualized Lewis's conceptualist pragmatism but kept its overall structure: Categorial concepts are those that are more at the center of the web of belief (so they are not a priori as the a priori has been traditionally conceived), they are justified in terms of their pragmatic utility (for example, in predicting events), and they are subject to change or being given up when they no longer serve certain purposes as well as others. ${ }^{20}$

The other line of thought that followed in Lewis's wake dismissed the "given" under the pressure of Sellars's general criticism of all forms of givenness and his more specifically focused criticisms of the given as a sensory content that could serve in any way as premises in cognitive activity (carried out in his canonical "Empiricism and the Philosophy of Mind"). ${ }^{21}$ Once the sensory "given" had been rejected, the resulting three pronged image that itself came from Lewis's framework became canonical: There is a causal interaction between organism and environment (best studied by neuroscientists and empirically minded psychologists), which elicits a series of normative inferences that are not themselves based on any further inference but are simply set in motion by the input, and a learned disposition to utter phrases such as "Whoa, that's red, all right" and even more complicated phrases such as "There's a rabbit." Learning to respond to inputs in ways that adequately embody the inferential network of one's beliefs is itself a causal process - it has to be, since otherwise without an immediate given, there would be an infinite regress of inferences - an idea which is best encapsulated in Robert Brandom's concept of reliably differential responsive dispositions..$^{22}$ We are trained as youths to respond to wavelengths of light between $620-750 \mathrm{~nm}$ (red light) in ways that in English come out as something like "Ooh, red." It is not the case that we see a qualia, grasp its category in English, and then infer to "Ooh, red" - we simply are trained to respond those wavelengths in certain ways, and when things go right we acquire the dispositions that turn us into reliable responders who can perform subtly differentiated responses.

This picture also is at work in Richard Rorty's views on mind and world, ${ }^{23}$ and it seems to be the picture at work in Donald Davidson's equally influential views. ${ }^{24}$ It reaches its apotheosis in Brandom's explication of it. Brandom takes Lewis's framework, transforms concepts into inferential links, discards the Lewisian sensory given and substitutes a generalized concept of "the physical process that occurs between organism and world in the organism's sensing of the world," and keeps the naturalized concept of our being trained (which leans on inherent dispositions in the species) into responding in certain ways. We pass from sensing beings to sapient beings when we learn to move fully in the inferential patterns which are embodied, as Lewis puts it, in a concept's "internal (essential or definitive) relationships with other concepts" (1929: 83) (which Brandom takes to be formal and material inferential relationships, where material inferences are those like, e.g., "if X is red, then it is not green"). Common to all these is an idea that the test, the rationale, for operating with one interpretive scheme over another is that of predicting the future and thus learning to control it in some way. ${ }^{25}$ That is the "pragmatic" in "conceptualist pragmatism."

\section{V}

21 To those familiar with German Idealism, Lewis's system most obviously bears a resemblance to Fichte's post-Kantian philosophy. Like Fichte, Lewis dispenses with the 
very idea of an in principle unknowable thing-in-itself, ${ }^{26}$ and like Fichte, he thinks that there is progress in knowledge which ends only at infinity (in other words, which has no ending). ${ }^{27}$ For that matter, Lewis himself even states his affinity with Fichte: "This interpretive fiat is what Fichte stresses as the positing of the "not-me"' (1929: 46).

The resemblance starts from Fichte's own commencement with the conception of a thinking agent so that for the agent's thinking (the "I") to have any real authority, the agent must posit - that is, authorize - that there is something entirely distinct from its thinking (the "Not-I") which exercises authority over thinking. That is, thinking must acknowledge its absolute authority to bestow authority on something else to exercise its authority against thinking, and without that bestowal of authority, the "Not-I" could have not authority at all. As it were, the perceptual object must be endowed by the thinking agent with the authority to determine if the thinking agent's thought about it is authoritative. The rest of Fichte's system is more or less bound up with trying to make sense of how that seeming contradiction could possibly work itself out into something less seemingly paradoxical. Lewis himself, however, thinks that the paradox in Fichte's beginning is never resolved, and he offers his own diagnosis of why.

Fichte wonders where the mind (or the conceptual framework itself) gets its initial authority to do this, and he claims that the only alternative is to think of the mind positing itself as exercising such authority in the first place and then going on to think of this authority as requiring of itself that something other than mind give it both determinate content and real authority - a kind of "I authorize it to tell me what I can authorize." Fichte starts from a conception of unity or oneness of mind with itself and then goes on to see how mind fractures itself into two in seeking its own unconditional epistemic authority. Lewis, on the other hand, argues that we must begin with a fundamental dualism between concept and sensory given (the "I" and the "Not-I"), and his argument boils down to the claim that we can in the last analysis make no sense at all of what it would mean for mind "to create or constitute itself" as Fichte seems to think. ${ }^{28}$ Lewis's alternative to Fichte thus goes: Our conception of a mind already includes the limitation of its conceptual capacities by something not conceptual which is given to us via our senses. We begin with a dualism, not institute it out of some more original unity. If anything, this puts Lewis squarely into the debate the German idealists had among themselves. The post-Kantians were all united in their rejection of Kant's conception of the a priori forms of intuition (although for varying reasons). An influential traditional interpretation of that rejection had the post-Kantians committed to the view that, once we have rejected Kant's forms of pure intuition, there was no cognitive role for intuitions to play at all, and as a result they then thought the "mind" (now hypostatized and, as it were, cosmologized) constructed itself and its content without reliance on intuition at all (or that intuitions were themselves such constructs). However, that was not the postKantian view really at all, since they were all deeply worried about the place that sensible intuitions played in cognition. None of the major figures thought (contra the often received view) that the sensible was formless, but they also did not think that it carried a form with itself that limited conceptual thought in any kind of way that would lead to some conception of an in principle unknowable realm of things in themselves.

Lewis also rejects the possibility that we impose conceptual form on a formless sensibility, and he also does not think that our sensory capacities come with any a priori form on their own. ${ }^{29}$ (The a priori for him is to strictly restricted to the conceptual sphere.) On Lewis's picture, human mindedness is not a matter of rules being applied to 
formless data. Comprehensibility has to include both sides within itself: Concepts (as a priori categories) and sensibility (as the given of qualia).

In particular, Hegel's worry about Fichte's way of proceeding was, put most simply, that Fichte's way was seductively and misleadingly concrete. Fichte speaks of the "I" positing itself as positing its other, its "Not-I," and that way of speaking conjures up a picture of a determinate object: An individual person, perhaps looking out a window or staring at a screen, thinking about something, maybe feeling an ache in his or her leg, perhaps consumed with thinking about some philosophical issue, or maybe fully absorbed in an activity such as slicing vegetables. That is, not, however, the "I" that Fichte has in mind, so speaking of an "I" in this case is deceptive. To get a grasp on Fichte's core idea, though, we must make things more abstract before we can make them more concrete. This too was more or less Lewis's view.

Hegel's own response, most generally stated, is the idea that the conceptual includes as a constitutive element of itself the sensible, not because we impose the conceptual on the sensible or somehow mix them together like oil and vinegar in a salad dressing, but because conceptuality includes the very concept itself of responsiveness to its other, sensibility. Hegel calls this the concept's "negativity" for good reason: It forms what in current philosophical jargon is usually called these days "normativity," the possibility of a judgmental (the use of concepts) appraisal as true or false, adequate or inadequate, etc. Our sensibility cannot be conceived except as a component of our conceptuality, and vice versa. This led to what Hegel knew in advance would be one of more difficult thoughts, namely, his beginning his Logic with the concepts of being and nothing as both equivalent and distinct. "Being," or the "is-ness" of things is an empty concept; it is not a thing, not a distinct item that could be thought or intuited and therefore cannot be distinguished from "nothing"; and therefore as Hegel puts it, "Pure being and pure nothing are therefore the same [...] But the truth is just as much that they are not without distinction; it is rather that they are not the same, that they are absolutely distinct yet equally unseparated and inseparable" (Hegel \& Di Giovanni, 2010: 59-60). Thus, the thought of being and nothing turns out not to be an adequate thought at all wholly within its own internal standards, since it contradicts itself, and, again to resort to Hegel's own words, "it therefore contradicts itself in itself, because what it unites within itself is self-opposed; but such a union destroys itself" (ibid.: 81). This finally gets fleshed out into Hegel's view that "the concept" has within its own self-conception (the concept of the concept) its own otherness - concept and sensibility are two distinguishable but inseparable components of mind..$^{30}$

This is part of Hegel's fundamental appropriation of Kantianism. Whereas Fichte, Schelling and even Hölderlin had begun with the conception of an original unity that necessarily fractures itself and then seeks to restore that unity - a version of a basically Judeo-Christian story of the Fall - Hegel begins with the fracture itself. It is not that one has unity ("being") and then disunity ("being and nothing"). The fracture is there at the outset and there is no way of overcoming or abolishing it. As Hegel explicitly states: "being has passed over into nothing and nothing into being - 'has passed over,' not passes over" (Hegel \& Di Giovanni, 2010: 59). What had presented itself as a fully thinkable judgment - "Being, pure being [...] In its indeterminate immediacy it is equal only to itself and also not unequal with respect to another" (ibid.) - turns out not to be an adequately thinkable judgment at all. It turns out to be a deeply flawed thought that cannot be 
further entertained as it was but has to be altered in order to preserve whatever sense it originally seemed to have.

What is perhaps surprising is Lewis's own rather Romantic response to such an issue: "That mind is thus continuous with the finally mysterious is-ness of what is - we must of course grant; in the contemplation of mind we contemplate one aspect of the Great Fact in the presence of which all explicit thought is silenced" (Lewis, 1929: 236-7). Lewis's response sounds oddly more like Heidegger, maybe even like Wittgenstein in the Tractatus, ${ }^{31}$ or perhaps even a bit like Schelling. ${ }^{32}$ The original unity of mind and world is not explicable in terms of any of the categories. Indeed, Lewis seems to be committed to the idea that since such an original unity could not be conceptually comprehended or sensibly given, that it could not really be "thought" at all and thus must be met with "silence" even though it a necessary consequence of our thought (Lewis's "it must be granted...”). To take it further: Lewis's response is even a bit Kantian in spirit, resembling roughly what Kant said about the experience of natural beauty: It is the indeterminate concept of something that is neither nature nor spirit (that is, neither "given" nor "concept") that is the common ground of both and thus is the basis of freedom. ${ }^{33}$

Whatever else it is, Lewis's response is not Hegelian. The idea of a thought of the final ground of all things, the absolute, as something beyond any conceptual grasp, to be accompanied by silence, was anathema to Hegel. He famously called (what was clearly Schelling's version of it) the night in which all cows are black. He also noted about such views: "There is nothing to be intuited in it, if one can speak here of intuiting; or, it is only this pure empty intuiting itself" (Hegel \& Di Giovanni, 2010: 59). It is not that he thought that we knew everything, would ever know everything, or that we have reached some point like the mythical end of history. The absolute which thought grasps in Hegel's system is indeed unconditional, but it is the unconditional grasp of itself as completing its task only at infinity (that is, never at any point in time), and this timeless unconditional, absolute grasp of itself and its project counts for it counts as "the absolute." Moreover, such a conception of the absolute is not merely the rather formal conception of the absolute as, say, succeeding only in that it succeeds in knowing in an absolute fashion that it must fail at what it most wants to do - something like that is more akin to Kant's conception of reason's only possible success - but a comprehension of itself that can only emerge after it has exhausted the available alternatives and seen both how those alternatives are lacking, how they push on to this conclusion, and how they shape the way the conclusion has to form itself. (At the end of his life, Hegel noted to himself about how in the period surrounding his writing his Phenomenology that the prevailing conception of the absolute was at that time an abstract conception..$^{34}$ Presumably, he meant that he had now gone beyond that abstraction.) In effect, conceptuality comprehends itself only in its development of its own self-consciousness about itself, and that includes the difficult Hegelian conception of the concept's otherness within itself, the idea that the determinateness of a concept has to do with how it incorporates something non-conceptual - the world - into itself, how conceptual capacities, as it were, come with the idea of responding to the claims of sensibility. ${ }^{35}$

31 This is also because the Hegelians (and the Schellingians too, although in a different way) think of these capacities as making sense only within the context of the human life-forms in which they manifest themselves. As earlier noted, the metaphor of the organic rather than the mechanical played a key role in both Schelling's and Hegel's way of presenting more easily digestible pictures of their views. Roughly put, the mechanical metaphor sees 
sensibility and conceptuality as each existing apart from the other like modules in a machine and as working together harmoniously when the machine is functioning correctly (more or less as the components of a well functioning mechanical watch work). The organic metaphor sees sensibility and conceptuality as two, as it were, organs serving the purposes of the organism, such that the determinateness of neither organ could be specified outside of its role in the life of the organism as a whole. Neither can be given its rightful determinacy outside of the way it functions in human life. For each animal lifeform, the world shows up in a certain way given the way its neurophysiological system works in connection to its environment. Lettuce shows up to rabbits as food, rabbits show up to foxes as food (and foxes show up to coyotes as food, and on and on). The world shows up to self-conscious humans in a way in which the conceptual always figures in it. As Hegel notes, the world itself shows up as pointing to infinity (as there being always "one more" in time, in space, and so on), and such infinity can only show up to selfconscious creatures since infinity can only be a topic of pure thought, never of purely sensuous experience. Thus, for Hegel, Fichte's mistake was in thinking that subject or object, one or the other, had to have priority in a truly rigorous account of knowledge and valuation, and Fichte was thus misled into thinking it had to be something concrete: the thinking, active subject, the "I." The thinking, active subject, however, appears only once we have understood the basic way in which thinking is both the unity of an original fracture between sensibility and concept and requires self-consciousness.

In Mind and the World Order, Lewis often speaks as if the two capacities of sensibility and conceptuality were fully independent modules, but if that were true, then their functioning together would have to come from a purpose external to both of them (as it does to the parts of the mechanical watch) instead of each being what it is in terms of a purpose that is internal to the organism itself.

Lewis does not discuss in any except a passing manner the way in which the pragmatic application of the conceptual apparatus is part of the purposiveness of the organism, but he does discuss how the like-mindedness of human knowers is based on facts about the kind of creatures they are - or, to use a non-Lewisian formulation, how it is based on their form of life. ${ }^{36}$ If he took that more seriously, it would lead him away from his more mechanically sounding and into a more Hegelian-Schellingian-Deweyian stance which would be more appropriate to his own system. ${ }^{37}$ It would also have required him to probe more deeply into what he acknowledged was mind as a social product and to explore the first person singular and plural and how the second person address builds from one to another, as Hegel did in his Phenomenology. The very concept of self-conscious life itself what Hegel decided to call Geist - involves the conceptions of a first and second-person address which then builds itself up into a first-person singular and plural (an I and a We). 38

At that point, the paths traced by idealism and conceptualistic pragmatism would have met. ${ }^{39}$ To appropriate an image from another philosopher, both the older idealists and the newer pragmatists would find Hegel waiting at the end of the path for all of them, arms folded, saying that he had known all along they would be coming that way. Generational experiences often lead to odd crossroads. 


\section{BIBLIOGRAPHY}

BALDWIN Thomas, (2007), “C. I. Lewis: Pragmatism and Analysis,” in Michael Beaney (ed.), The Analytic Turn: Analysis in Early Analytic Philosophy and Phenomenology, London, Routledge, 178-95. BRANDOM Robert, (2000), Articulating Reasons: An Introduction to Inferentialism, Cambridge, Mass., Harvard University Press, $230 \mathrm{p}$.

BURGE Tyler, (2009), "Primitive Agency and Natural Norms," Philosophy and Phenomenological Research, LXXIX (2), 251-78.

FARRELL Frank B., (1994), Subjectivity, Realism, and Postmodernism: The Recovery of the World, Cambridge, New York, Cambridge University Press, xii, 290 p.

FICHTE Johann Gottlieb \& Daniel BREAZEALE, (1988), Fichte, Early Philosophical Writings, Ithaca, N.Y., Cornell University Press, xx, 455 p.

FRIEDLANDER Eli, (2001), Signs of Sense: Reading Wittgenstein's Tractatus, Cambridge, Mass., Harvard University Press, $\mathrm{xx}, 227 \mathrm{p}$.

FRIEDLANDER Eli, (2014), “Missing a Step Up the Ladder," Philosophical Topics, 42 (2), 45-73.

HEGEL Georg Wilhelm Friedrich \& Johannes HOFFMEISTER, (1961), Briefe von und an Hegel, 4 vols., [2. unveränderte Aufl.] edn., Hamburg, Felix Meiner.

HEGEL Georg Wilhelm Friedrich, WESSELS Hans-Friedrich \& Heinrich CLAIRMONT, (1988), Phänomenologie des Geistes, Philosophische Bibliothek, Hamburg, F. Meiner Verlag, xc, 631 p. HEGEL Georg Wilhelm Friedrich \& George DI GIOVAnNI, (2010), The Science of Logic, Cambridge Hegel translations, Cambridge, New York, Cambridge University Press, lxxiv, 790 p.

HEGEL Georg Wilhelm Friedrich \& Terry P. PINKARD, (2018), Georg Wilhelm Friedrich Hegel: The Phenomenology of Spirit, New York, Cambridge University Press, pages $\mathrm{cm}$.

KANT Immanuel \& Werner S. PLUHAR, (1987), Critique of Judgment, Indianapolis, Ind., Hackett Pub. Co., cix, $576 \mathrm{p}$.

LEWIS Clarence Irving, (1929), Mind and the World-Order; Outline of a Theory of Knowledge, New York, Chicago, C. Scribner's Sons, xiv p., 1 l., 446 p.

LEWIS Clarence Irving, (1947), An Analysis of Knowledge and Valuation, La Salle, Ill, Open Court.

MCDOWELL John Henry, (1994), Mind and World, Cambridge, Mass., Harvard University Press, x, 191 p.

MENAND Louis, (2001), The Metaphysical Club (1st edn.), New York, Farrar, Straus, and Giroux, xii, $546 \mathrm{p}$.

MISAK Cheryl J., (2013), The American Pragmatists (1st edn., Oxford History of Philosophy), Oxford, Oxford University Press, xvi, $286 \mathrm{p}$.

PINKARD Terry, (2007), "Was Pragmatism the Successor to Idealism?," in C. J. Misak (ed.), New Pragmatists, Oxford, New York, Clarendon Press, Oxford University Press, 142-68. 
PIPPIN Robert B., (2005), “Concept and Intuition: On Distinguishability and Separability,” HegelStudien, 40.

PIPPIN Robert B., (2018), Hegel's 'Realm of Shadows': Logic as Metaphysics in "The Science of Logic," Chicago, University of Chicago Press.

ROBINSON Henry Crabb, ROBINSON Thomas \& Edith J. MORLEY, (1929), Crabb Robinson in Germany, 1800-1805; extracts from his correspondence, London, H. Milford, Oxford University Press, 4 p.l., 194 p., 11 .

RORTY Richard, (1991), Objectivity, Relativism, and Truth, Philosophical Papers, Cambridge, New York, Cambridge University Press, x, 226 p.

SCHELLING Friedrich Wilhelm Joseph von \& Peter Lauchlan HEATH, (1978), System of Transcendental Idealism (1800), Charlottesville, University Press of Virginia, xxxvi, 248 p.

SELLARS Wilfrid, RORTY Richard \& Robert BRANDOM, (1997), Empiricism and the Philosophy of Mind, Cambridge, Mass., Harvard University Press, 181 p.

\section{NOTES}

1. See Louis Menand's delightful but limited account in The Metaphysical Club (2001). Menand overstates the influence of the Civil War and overly ascribes the pragmatist movement to traits of certain key personalities, but he does bring out the generational aspect of the shift to pragmatism.

2. In his 1823 letter to Duboc, a Hamburg hat-maker, Hegel explained that he had nothing against the doctrines of the Scottish philosophers about realism, namely, that the objects of knowledge are independent of our representations of them. What he took issue with was the idea that "things are what they are" - which he rendered in his own terms as "Übereinstimmung des Seins mit sich selbst" (or "the correspondence of being with itself") - is itself intelligible without comprehending that this too is a "thought-determination" (Denkbestimmung) and is thus the proper subject of the logic of thought itself. See Hegel \& Hoffmeister (1961: Briefe \#450, p. 12).

3. The young Schelling had a particular animus to seeing the value of new industrial technology in the context of modern life. As Schelling supposedly told Henry Crabb Robinson, "It is absurd to expect the science of beauty in a country that values the Mathematics only as it helps to make Spinning Jennies and \& Stocking-weaving machines," cited in Robinson, Robinson \& Morley (1929: 118).

4. In her treatment of Lewis, Cheryl Misak (2013: 191) also describes, rightly, Lewis' position as being that of a Kantian pragmatist. In taking Lewis' "conceptualist pragmatism" as a direct descendant of Charles Peirce's version of pragmatism, Misak also incorporates and corrects much of the still rather meager commentary on Lewis. She also shows the close link between Lewis' position as it was taken up at the time and the emerging school of logical empiricism in Vienna (which Lewis predated). Because of the perceived similarities between Lewis and the Vienna school, Lewis' position was much easier to integrate into the emerging paradigm of linguistically oriented analytical philosophy than was, for example, Dewey's.

5. See Lewis (1929: 259). Lewis does not explicitly mention inference on that page, but it follows from what else he says about inference at other parts of the book, such as when he claims: "The nature of a concept as such is its internal (essential or definitive) relationships with other concepts" (ibid.: 83). He justifies his relative lack of discussion of inference as constituting concepts by noting, "The most important topic in this connection would be the meaning of implication and the nature of inference. But examination of that question would of necessity be 
too long and complex for inclusion here" (ibid.: 433). To distinguish these a priori concepts from others, Lewis coins the term "categorial" to demarcate them: "'Categorial' is used throughout with the meaning 'pertaining to the categories.' This avoids possible confusion with meaning specifically 'unconditional, not hypothetical"' (ibid.: 12, footnote).

6. See (ibid.: 82): "Logical analysis is not dissection but relation; the analysis of A into Band C does not divide A into constituents Band $\mathrm{C}$ but merely traces a pattern of relations connecting A with Band C. As regards their conceptual meaning, terms are very closely analogous to points in space. A point is nothing whatever apart from its relation to other points; its very essence is relational. Likewise the conceptual meaning of a term is nothing whatever apart from other such meanings." This inferential, relational emphasis in Lewis is a point stressed in Baldwin 2007.

7. See among other instances Lewis (ibid.: 87-8): "In such cases the meaning is possessed by the mind both in the sense of this consistently determined attitude and in the further sense that how this meaning should become explicit and what would be recognized as essential, when the attitude became self-conscious, is already implicit in the attitude." Lewis also claims that "identity of meaning consists practically in implicit modes of behavior, and what is involved in these always runs beyond what can be explicit in consciousness at any one time" (ibid.: 84).

8. As is well known, McDowell carries out his own critique of the myth of the given in terms of Gareth Evans's defense of a version of it in Mcdowell (1994).

9. See (ibid.: 61, 124).

10. See the discussion of how Lewis's conception of the given differs fundamentally from the empiricist model often attributed to him in Misak 2013.

11. Lewis (1929: 432): “This, as it seems to me, but serves to emphasize the fact that the conceptual interpretation of experience is, at bottom, something concerning which rationalistic accounts and empiricistic theories are, in their opposite ways, both false, and the pragmatic is the true one."

12. (Ibid.: 21): "Our categories are guides to action." And, p. 93: "Our common world is very largely a social achievement - an achievement in which we triumph over a good deal of diversity in sense-experience."

13. See (ibid.: 113): “'Like-mindedness' consists primarily of three things; the possession of like needs and of like modes of behavior in satisfying them, second, the possession of common concepts, represented in behavior by discrimination and relation, and third, the capacity (evoked particularly when community in the other two respects threatens to fail) of transcending our individual limitations of discrimination by indirect methods."

14. Lewis also notes: "Identity of meaning consists practically in implicit modes of behavior" (ibid $.84)$.

15. (Ibid.: $\mathrm{x}$ ): "The choice of conceptual systems for such application is instrumental or pragmatic, and empirical truth is never more than probable."

16. See (ibid.: 117, 58).

17. See (ibid.: 37): "The pure concept and the content of the given are mutually independent; neither limits the other." Likewise, p. 220: "An absolute and a priori limitation of experience could not be known." Lewis seems to backpedal on this in one other passage, where he says, "The qualia of the given are the clue to the applicability or inapplicability of concepts and set the the limits of conceptual interpretation" (ibid.: 157). If qualia are the content of the given, and the content of the given does not limit the pure concepts, then it is difficult to see how qualia "set the limits of conceptual interpretations." Perhaps somebody has an idea on how to square the circle on the this, but I tend to think of it as an indication of a basic and irresolvable tension in Lewis's thought.

18. See (ibid.: 247): “Genuine issues may of logic are those which stand above such questions of the merely self-critical integrity of the logical system. There are such issues, and these cannot be 
determined - nay, cannot even be argued - except on pragmatic grounds of human bent and intellectual convenience."

19. This rather constricted conception of the normative goes against the more expansive conception to be found in the "organic pragmatism" of John Dewey's thought, and against the more expansive view to be found in German idealism. It also runs up against other types of views that argue for a non-representationalist, non-conceptual meaning of "norms" to be found in even simple organic life. For the view that such normativity is conceptually more basic than that of representations, see Burge 2009.

20. As Lewis states his own case: "New ranges of experience such as those due to the invention of the telescope and microscope have actually led to alteration of our categories in historic time [...] Categories and concepts do not literally change; they are simply given up and replaced by new ones"(1929: 268).

21. Sellars, Rorty \& Brandom 1997.

22. Brandom (2000: 118): “The empiricist tradition is right to emphasize that our capacity to have empirical knowledge begins with and crucially depends on such reliable differential responsive dispositions. But though the story begins with this sort of classification, it does not end there. For the rationalist tradition is right to emphasize that our classificatory responses count as applications of concepts, and hence as so much as candidates for knowledge, only in virtue of their role in reasoning. The crucial difference between the parrot's utterance of the noise 'That is red' and the (let us suppose physically indistinguishable) utterance of a human reporter is that for the latter, but not the former, the utterance has the practical significance of making a claim. Doing that is taking up a normative stance of a kind that can serve as a premise from which to draw conclusions. That is, it can serve as a reason for taking up other stances."

23. See Rorty 1991.

24. See the discussion of Rorty's and Davidson's views in Frank B. Farrell 1994.

25. (Ibid.: 357-8): "Knowledge of reality serves for the control of experience: without the possibility of control, not only would knowledge be worthless, there would be for us no reality to know."

26. (Ibid.: 236): "If we should think of mind as what the rationalists suppose - superimposing on reality a rigid mask of form outside which mind itself could never catch a glimpse - then this altogether universal and un-get-overable form could never become self-conscious. It would remain - in Fichte's phrase - the 'Great Thought which no man has ever thought'."

27. Fichte \& Breazeale (1988: 122): "Consequently, the spheres of activity of the particular sciences are infinite. Thus an exhaustive Wissenschaftslehre presents no threat to the human mind's infinite progress toward perfection. The Wissenschaftslehre does not negate this infinite progress; on the contrary, it provides it with a foundation which is totally secure and beyond all doubt. It assigns to the human mind a task which it cannot complete in all eternity."

28. (Ibid.: 425).

29. (Ibid.: 236-7): "But the categories are not the form of that which, having no alternative and no bounds, is formless. They are the explicit bounds of that which, if it transcend them, must fall into some other category. They are divisions within the comprehensible in general, but not the shape of comprehensibility itself."

30. See Robert B. Pippin 2005. See also (forthcoming): Robert Pippin 2018.

31. For an interpretation along that line, see Friedlander 2001, and 2014.

32. "But now it is obvious that if there were not an absolute limit to knowledge - something that, even without our being aware of it, also absolutely fetters us and binds us in knowledge, and that, in the course of knowing never once becomes an object, precisely because It is the principle of all knowledge - then we could simply never arrive at knowledge, even of one solitary thing [...] there is an ultimate of some sort, from which all knowledge begins, and beyond which there is no knowledge" (Schelling \& Heath, 1978: 16). The resemblance to Schelling is made more curious by 
Lewis's one reference to Schelling (in relation to Fichte) in which it is hard to see if he is endorsing Schelling (or probably more likely) adopting a fully ironic tone: "Schelling however, acknowledges the justice of the challenge and seeks to meet it with amazing results. Starting from the Fichtean premise, A = A, he deduces eventually the electrical and magnetic properties of matter!" (Lewis, 1929: 190, footnote).

33. Kant speaks of judgments of the beautiful as where "judgment finds itself referred to something that is both in the subject himself and outside him, something that is neither nature nor freedom and yet is linked with the basis of freedom, the supersensible, in which the theoretical and the practical power are in an unknown manner combined and joined into a unity" (Kant \& Pluhar, 1987: §59, p. 229 (354)).

34. See Hegel, Wessels \& Clairmont (1988: 552); Hegel \& Pinkard (2018: 469).

35. Hegel thus says, "For the sake of freedom, the Idea also has [...] the hardest opposition within itself; its being at rest consists in the security and certainty with which it eternally creates and eternally overcomes that being at rest and therein brings itself together with itself' (Hegel \& Di Giovanni, 2010: 759).

36. See formulations such as “'The human mind' is distinctly a social product, and our categories will reflect that fact [...] The human animal with his needs and interests confronts an experience in which these must be satisfied, if at all. Both the general character of the experience and the nature of the animal will be reflected in the mode of behavior which marks this attempt to realize his ends. This will be true of the categories of his thinking as in other things" (Lewis, 1929: 238-9).

37. See Pinkard 2007.

38. See Hegel \& Pinkard (2018: \177), where Hegel begins with a second-person encounter, "A self-consciousness is for another self-consciousness," which he then goes to argue culminates in a first-person singular and plural: "[...] in the oppositions of the various self-consciousnesses existing for themselves: The I that is we and the we that is I" (ibid.: 108).

39. Lewis himself resisted that path and in his later work drew closer to the empiricism that was starting to prevail in American philosophy. Clarence Irving Lewis 1947. A good account and more or less a limited defense of it can be found in Misak 2013.

\section{ABSTRACTS}

C. I. Lewis's version of pragmatism, which he called "conceptualistic pragmatism," has been little studied and is nowadays overlooked, eclipsed by the more famous pragmatisms of Dewey and James. However, it was Lewis's version that came to dominate the formation of post-1945 pragmatism in the United States. It provided the framework in which Quine (his former student), Sellars, Davidson, Rorty and Brandom operated. Roughly, that structure involved a passive, sensory ineffable given and an ordering and classification of the given by a priori categories. Comprehending those categories was a matter of apprehending a priori truths, but those categories were also changeable. Rational change involved giving some up and substituting others to meet certain basic human interests. We thus have the picture of mind and world that culminates in a certain sense in Brandom's philosophy: External causal inputs linked to an internal normative inferential network which then results in causal outputs of linguistic shape. This is very different from the classical German idealist conception of mind and world, which takes the distinguishability-but-inseparability of concept and sensory intuition as its core. 
AUTHOR

TERRY PINKARD

Georgetown University

Terry.Pinkard[at]georgetown.edu 